\title{
Effect of Industrial Bleach Wash and Softening on the Physical, Mechanical and Color Properties of Denim Garments
}

\author{
Joy Sarkar ${ }^{1}$, Elias Khali1 ${ }^{2}$ \\ ${ }^{I}$ Department of Textile Engineering, Khulna University of Engineering \& Technology, Khulna-9203, \\ Bangladesh \\ ${ }^{2}$ Department of Textile Engineering, World University of Bangladesh, Dhaka-1205, Bangladesh
}

\begin{abstract}
Garments washing is a novel process to impart worn-out look, to modify the appearance and to improve the comfort ability of the garments. Bleach wash is used to fade the color of denim in a higher degree as well as bleach wash has effect on the physical and mechanical properties of the denim also. This paper presents the impact of bleach wash and subsequent softening treatment on $100 \%$ cotton denim dyed with indigo dye. Garments were washed using a bleach concentration of $10 \mathrm{~g} / \mathrm{l}$ for 30 minutes in $50^{\circ} \mathrm{C}$ temperature and then softened using standard recipe. The physical, mechanical and color properties were analyzed in before wash, after desizing, after bleaching and after softening. The properties that were analyzed include hand feel, tensile strength, seam strength, fabric weight, stiffness, dimensional stability and color fading. Bleach washed and softened garments exhibit a great difference in the physical, mechanical and color properties than the unwashed garments.
\end{abstract}

Keywords: Denim, Bleach Wash, Garments Washing, Softening

\section{Introduction}

In the readymade garments industry sector garments washing is a new technology. After making garments from solid color from dyed or pigment printed fabrics, the garments are washed by garments washing, color and outlook of the garments are modified [1].

As a result new outlook and appearance is produced in the garments, which is not possible in any other method. Moreover, due to washing, starch present in the garments is removed [1]. As a result washed garments could be worn after purchase directly from the store or shop. Some garments shrink after wash, hence washed garments could be purchased as per required size [2].

Among different techniques of garments washing, bleach wash is chosen to fade a higher degree of color. It is very difficult without bleach wash, to fade the color from all over the garments at one wash in such a higher degree. That's why despite of having some drawbacks like- bleach decomposes the cellulose hence destroys the fabric, tends to make the fabric yellowish, needs to be neutralized hence increases cost and adds a more step to the processing time the bleach wash cannot be avoided. Besides these drawbacks, bleaching agents especially chlorine bleaches are health hazardous and the effluents are hazardous to the environment [3], the process controlling is very tough and same results cannot be achieved in every batch even after following the same recipe [4].

Bangladesh is a country where ready-made garments are the top export item and among ready-made garments the share of woven items is maximum [5]. Among woven items denim garments have a mentionable share. This paper investigates the impact of bleach wash on not only the color properties of denim but also the physical and mechanical properties as these properties determines the wearers feel and life of the end product.

\subsection{Materials}

\section{Materials And Methods}

$100 \%$ cotton denim leg panels were used. These comprised indigo dyed denim fabric, GSM (Grams per Square Meter) 381, 3/1 warp faced twill, construction $74 \times 42 / 9 \times 7$, fabric width 57 inch. The leg panels were desized using the standard recipe. Then the denim leg panels were washed using bleaching powder. Washed denim leg panels were then neutralized with hyposulphite.

Bleaching powder (KCI bleach, India); detergent (Hostapur WCTH, Germany), desizing agent (Luzyme FR-HP, BASF, Germany); neutralizing agent sodium hyposulphite (Hypo, China); softener (ResilAOEC, Resil, India) were used.

\subsection{Methods}

\subsubsection{Desizing Process}

Denim leg panels were desized using detergent and desizing agent. This pretreatment was conducted in liquor containing detergent, Hostapur WCTH $(1.0 \mathrm{~g} / \mathrm{l})$ and desizing agent, Luzyme $(0.6 \mathrm{~g} / \mathrm{l})$, and material 
to liquor ratio of 1:10 in a small scale front loading industrial washing machine (Sutlick, Singapore). This treatment was carried out at temperature $60^{\circ} \mathrm{C}$ for $20 \mathrm{~min}$. After desirable time the liquor was dropped out. The leg panels were then washed with hot water at $60^{\circ} \mathrm{C}$ for $3 \mathrm{~min}$ then washed twice with cold water for $3 \mathrm{~min}$ each.

\subsubsection{Bleaching process}

Desized denim leg panels were treated using bleaching powder. This process was conducted in liquor containing $\mathrm{KCI}$ bleach $(10 \mathrm{~g} / \mathrm{l})$, soda ash $(5 \mathrm{~g} / \mathrm{l})$ at $\mathrm{pH} 10.5$, and material to liquor ratio of 1:10 in the washing machine. Temperature was kept $50^{\circ} \mathrm{C}$ and treatment time $30 \mathrm{~min}$. The denim garments were then neutral washed in a liquor ration 1:10 with Hypo $(2 \mathrm{~g} / 1)$, Acetic Acid $(40 \mathrm{gm}$.) to maintain the $\mathrm{pH}$ of the bath 5.5 for $7 \mathrm{~min}$ at room temperature. Then the leg panels were rinse washed with only water for 2 minutes.

\subsubsection{Softening, Hydro-extracting and drying Processes}

Bleached washed leg panels were then softened with a softener. This treatment was conducted in a bath with a liquor ration of 1:10, containing Resil AOEC (2 g/L), acetic acid (40 gm.) to maintain $\mathrm{pH} 5.5$ in room temperature for 10 minutes.

Bleach washed and softened denim leg panels were squeezed to a wet pick-up of $70 \%$ at $200 \mathrm{rpm}$ for 3$4 \mathrm{~min}$ in laboratory scale hydro-extractor machine (Zanussi, Roaches International Limited, England), then dried at $63-64^{\circ} \mathrm{C}$ for $20 \mathrm{~min}$ in a steam drier (fabcare, India). Treated denim leg panels were then analyzed to determine their physical, mechanical and color properties.

\subsubsection{Softening, Hydro-extracting and drying Processes}

The treated denim leg panels were conditioned in $65 \% \mathrm{RH}$ and $20^{\circ} \mathrm{C}$ for 24 hour before testing according to BS EN 20139 and ASTM D1776 [6].

Tensile strength (breaking force) was determined by the US Standard Grab test method according to ASTM D 5034 [7]. Dimensional changes / shrinkage (\%) was calculated from the difference in fabric length before and after washed garment according to AATCC test methods 135 and 150; ASTM D 2724, BS 4931. Weight change (\%) in fabric / GSM was calculated from the difference in fabric weight before and after the treatment according to ASTM D 3776 [8]. Stiffness was measured from the bending rigidity in fabric by Shirley stiffness tester according to BS 3356 [9]. Seam strength of the samples was measured by seam strength tester according to ISO 13935-2: 2014. Change in the original color shade of the fabric was rated using Heal's Grey Scales for Assessing Change in Color (Batch C04) according to ISO 105 - A02: 1993.

\subsection{Effect of washing on feel of fabric}

\section{Results And Discussion}

The hand feeling of the fabric improves a lot after performing the washing and this improvement has been found in each successive stages of processing. After desizing process the hand feel has become soft than the before wash stage, but the fabric has become more soft after the bleaching process. After softening process the fabric exhibited the softest hand feel.

\subsection{Effect of washing on feel of fabric}

Table 1: Effects of bleach wash and softening on fabric specification

\begin{tabular}{|c|c|c|c|c|c|c|}
\hline Bleaching Stages & $\begin{array}{c}\text { EPI } \\
\text { (Ends/ Inch) }\end{array}$ & $\begin{array}{c}\text { PPI } \\
\text { (Picks/ } \\
\text { Inch) }\end{array}$ & Warp Count $(\mathrm{Ne})$ & $\begin{array}{c}\text { Weft Count } \\
(\mathrm{Ne})\end{array}$ & Fabric Weight (GSM) & $\begin{array}{c}\text { Shrinkage } \\
(\%)\end{array}$ \\
\hline Control & 74 & 42 & 9 & 7 & 383 & - \\
\hline After Desizing & $\begin{array}{c}75 \\
(+1.4 \%)\end{array}$ & $\begin{array}{c}44 \\
(+4.8 \%)\end{array}$ & $\begin{array}{c}9 \\
(0)\end{array}$ & $\begin{array}{c}8 \\
(+14.3 \%)\end{array}$ & $\begin{array}{c}381 \\
(-0.5 \%)\end{array}$ & $\begin{aligned} \mathrm{L} & =5.5 \\
\mathrm{~W} & =0.5\end{aligned}$ \\
\hline After Bleaching & $\begin{array}{c}75 \\
(+1.4 \%)\end{array}$ & $\begin{array}{c}45 \\
(+7.1 \%)\end{array}$ & $\begin{array}{c}9 \\
(0)\end{array}$ & $\begin{array}{c}7 \\
(0)\end{array}$ & $\begin{array}{c}372 \\
(-2.9 \%)\end{array}$ & $\begin{aligned} \mathrm{L} & =6.0 \\
\mathrm{~W} & =1.0\end{aligned}$ \\
\hline After Softening & $\begin{array}{c}76 \\
(+2.7 \%)\end{array}$ & $\begin{array}{c}46 \\
(+9.5 \%)\end{array}$ & $\begin{array}{c}10 \\
(+11.1 \%)\end{array}$ & $\begin{array}{c}8 \\
(+14.3 \%)\end{array}$ & $\begin{array}{c}369 \\
(-3.7 \%)\end{array}$ & $\begin{aligned} \mathrm{L} & =6.0 \\
\mathrm{~W} & =1.0\end{aligned}$ \\
\hline
\end{tabular}

$\mathrm{L}=$ Lengthwise (Warp Way) Shrinkage, $\mathrm{W}=$ Widthwise (Weft Way) Shrinkage.

It is clear from Table 1 that the desizing, bleaching a softening imparts significant change in the fabric properties. It has been found that, during these specific processing, the value of fabric surface density has been decreased. The Ends per Inch (EPI) and Picks per Inch (PPI) increased in a lower degree. The Shrinkage property has been found decreases, most significantly in warp way. Cotton fabrics are generally subjected to a considerable tension during weaving especially in the warp direction. This stretch was increased in subsequent finishing processes like calendaring and thus the stretch temporarily set in the fabric. The fabric is then in a state of dimensional instability [10]. When the bleach washing has been performed, the thorough wetting of the 
denim tend to bring the fabric back to its more stable dimensions which result in the contraction of the yarns. This effect is generally greater in the warp direction compared to the weft. This is known as relaxation shrinkage [10]. EPI (Ends per Inch) and PPI (Picks per Inch) was increased than untreated denim garments due to this relaxation shrinkage.

\subsection{Effect of washing on tensile strength of fabric}

Table 2: Effects of bleach wash and softening on fabric strength

\begin{tabular}{|c|c|c|}
\hline \multirow{2}{*}{ Bleaching stages } & \multicolumn{2}{|c|}{ Tensile Strength (lb) } \\
\cline { 2 - 3 } & Warp & Weft \\
\hline Control & 380 & 310 \\
\hline After Desizing & 377 & 305 \\
& $(-0.8 \%)$ & $(-1.6 \%)$ \\
\hline After Bleaching & 370 & 296 \\
& $(-2.6 \%)$ & $(-4.5 \%)$ \\
\hline After Softening & 365 & 292 \\
& $(-3.9 \%)$ & $(-5.8 \%)$ \\
\hline
\end{tabular}

The tensile strength in both warp and way has been decreased significantly. The highest decrement occurred after the bleaching treatment. Bleaching powder attacks the outer layer of the fabric surface and decomposes the dye and then slowly penetrates inside the fabric structure. The protruding fibers are decomposed and then the constituent yarns of the fabrics are attacked. By the decomposition of the aqueous solution of hypochlorite bleach, the chemical bonds of primary wall (outer layer) are broken. After that the secondary wall is attacked.

The frictional action (mechanical forces) of rotating cylinder of the washing machine assists in loosening and breaking down the primary cell wall of the cotton fiber [11].

\subsection{Effect of washing on seam strength}

Table 3: Effects of bleach wash and softening on seam strength

\begin{tabular}{|c|c|c|}
\hline Bleaching Stages & Seam Strength $(\mathrm{gm})$ & \% of difference \\
\hline Control & 92 & - \\
\hline After Desizing & 84 & $(-) 8.70$ \\
\hline After Bleaching & 72 & $(-) 21.74$ \\
\hline After Softening & 70 & $(-) 23.91$ \\
\hline
\end{tabular}

$(-\mathrm{Ve})$ Sign means reduction in seam strength

From Table 3 it is obvious that, processing in all the stages of bleach wash has influence in the decrement of the seam strength. The reduction in the seam strength also been assisted by the friction between the machine cylinder and the sample leg panels. The most significant decrement (23.91\%) in the seam strength occurred after the softening treatment

\subsection{Effect of washing on stiffness (Bending Length) of denim fabric}

Table 4: Effects of bleach wash and softening on stiffness

\begin{tabular}{|c|c|c|c|c|}
\hline \multirow{2}{*}{ Bleaching Stages } & \multicolumn{2}{|c|}{ Warp Way $(\mathrm{cm})$} & \multicolumn{2}{c|}{ Weft Way $(\mathrm{cm})$} \\
& Face & Back & 2.35 & Back \\
\hline Control & 4.33 & 4.00 & 2.33 & 2.55 \\
\hline After Desizing & 3.25 & 2.90 & $(-0.9 \%)$ & 2.54 \\
& $(-24.9 \%)$ & $(-34.5 \%)$ & 2.30 & $2.4 \%)$ \\
\hline After Bleaching & 3.19 & 2.64 & $(-2.1 \%)$ & $(-1.6 \%)$ \\
\hline After Softening & $(-26.3 \%)$ & $(-37.9 \%)$ & 2.30 & 2.50 \\
& 3.11 & 2.60 & $(-2.1 \%)$ & $(-1.9 \%)$ \\
\hline
\end{tabular}

The cotton fibers are loosened by bleaching treatment as the fibrils are degraded and partly detached from the main fiber chain, and softness increased. Moreover the size materials (Starch) are also removed from the warp yarns. As a result bending length was less and softness was increased. A significant change can be seen after the desizing as this step reduces most of the size materials from the fabric. As the size materials are removed from the warp yarns (as only warp yarns are sized), the reduction in the stiffness is very much significant in the warp way. 


\subsection{Effect of washing on color shade of denim fabric}

Table 5: Effects of bleach wash and softening on color fading

\begin{tabular}{|c|c|}
\hline Processing Stages & Grey Scale Rating \\
\hline Control & 5 \\
\hline After Desizing & $4 / 5$ \\
\hline After Bleaching & 3 \\
\hline After Softening & $2 / 3$ \\
\hline
\end{tabular}

It is obvious from Table 5 that, bleaching has changed the color of the denim significantly. A higher degree of color fading is achieved after the bleaching treatment. After desizing, a slight change in the color is observed compared to the before wash sample but the change in the color is vast after bleaching. The difference in color change is minimum in softening.

\section{Conclusion}

The bleaching and softening treatment have a great influence on the mechanical and color properties of denim fabric. The treated denim leg panels showed $2.6 \%$ strength loss in warp way and $4.5 \%$ in weft way. After softening this strength loss increased by $1.3 \%$ in both case. The seam strength decreased in successive processing stages. The highest reduction found was $23.91 \%$ after the softening treatment. The fabric weight reduced during the bleaching and softening. A loss of $2.9 \%$ in the initial fabric GSM has been observed after the bleaching and which is $3.7 \%$ after softening. The denims showed shrinkage in the warp way remarkably and which is $6 \%$ after bleaching and softening. The bleaching and softening both has great effect on the stiffness property of the denims especially in the warp way as the warps are mostly sized and the size materials are removed by the bleaching treatment. After bleaching the warp way stiffness has reduced $26.3 \%$ (face) and $37.9 \%$ (back). These values are $28.2 \%$ and $35 \%$ respectively after softening. The weft way stiffness has changed but not in a large scale. A reduction of $2.1 \%$ (face) and $1.9 \%$ (back) has been observed in weft way. The bleaching treatment has a great influence on the color change of the denims. After bleaching the grey scale rating was 3 where the initial rating was 5 which indicates a higher degree of color fading after the bleaching treatment. The grey scale rating after the softening has been observed $2 / 3$ which indicates a little variation in color than bleached denims.

It is clear that, the bleaching and softening treatment has a lot influence on the mechanical and color properties of the denim. The fading effect can be increased by the bleaching but bleaching also reduces the fabric weight, tensile strength and seam strength which might reduce the serviceability of the garments. So an optimum bleaching action is required to get the required fading effect and softness without compensating some important properties of denim

\section{References}

[1] M.A. Kashem, Garments merchandising (Dhaka: Lucky- One Traders, 2008)

[2] M.S. Azam, M.S. Saleh \& K.A. Nafiz, An introductory knowledge about garments manufacturing technology (Dhaka: Books Fair Publication, 2009)

[3] M. T. Islam, Garments washing \& dyeing (Dhaka: Ananto Publications, 2010)

[4] S. Pal, Technology of denim production: Part VI. Retrieved from http://www.fibre2fashion.com/

[5] Retrieved June 1, 2014 from http://www.bgmea.com.bd/chart test/exportOfWovenAndKnit/2013

[6] ASTM D 1776, "Standard practice for conditioning textiles for testing," American Society for Testing and Materials, Annual Book of ASTM Standards, vol. 7(1). ASTM International, West Conshohocken, PA, USA, 2008.

[7] ASTM D5034, "Standard test method for breaking force and elongation of textile fabrics (Grab test)," American Society for Testing and Materials, Annual book of ASTM Standards, 7(1), ASTM International, West Conshohocken, PA, USA, 2009

[8] ASTM D 3776, "Standard test methods for mass per unit area (weight) of woven fabric," American Society for Testing and Materials, Annual book of ASTM Standards, vol. 7(2), ASTM International, West Conshohocken, PA, USA, 1996.

[9] BS 3356, "Method for determination of bending length and flexural rigidity of fabrics," BSI Publisher, Chiswick High Road, London, UK, 1990.

[10] P.G. Cookson, Relationships between hygral expansion, relaxation shrinkage and extensibility in woven fabrics. Textile Research Journal, 62,1992,44.

[11] M.M.R. Khan, M.I.H. Mondal, \& M.Z.Uddin, Effect of bleach wash on the physical and mechanical properties of denim Garments. International Conference on Mechanical Engineering, 2011,3 